\title{
Petrogenesis and tectonic of the Urucum granitic suite, Rio Doce Valley (Minas Gerais - Brazil): an example of syn to late collisional peraluminous magmatism associated with high-angle transcurrent shear zone
}

Petrogênese e tectônica da suíte granítica Urucum, Vale do Rio Doce (Minas Gerais - Brasil): um exemplo de magmatismo sin- a tardicolisional associado a zonas de cisalhamento direcionais de alto ângulo

\author{
Hermínio Arias Nalini Júnior ${ }^{1 *}$, Rômulo Machado², Essaid Bilal ${ }^{3}$
}

\begin{abstract}
The Urucum suite (582 $\pm 2 \mathrm{Ma}$, zircon U-Pb age), situated in the Mid-Rio Doce Valley, eastern part of Minas Gerais State, is characterized by elongated, NW-SE and N-S trending granitic massifs associated with the Conselho Peńa-Resplendor high-angle shear zone. It corresponds to a syn to late collisional magmatism that presents dominant solid-state foliation. Four facies are distinguished within the Urucum suite: (i) a porphyritic (Urucum); (ii) a medium- to coarse nequigranular (Palmital); (iii) a tourmaline-bearing; and (iv) a pegmatitic facies. These facies are peraluminous, with alumina saturation index varying from 0.98 to 1.38 . $\mathrm{SiO}_{2}$ contents vary from 70.7 to $73.7 \mathrm{wt} \%$, with $\mathrm{K}_{2} \mathrm{O}$ values ranging from 3.5 to $5.7 \mathrm{wt} \%, \mathrm{Na}_{2} \mathrm{O}$ from 1.9 to $4.4 \mathrm{wt} \%$, $\mathrm{MgO}$ from 0.6 to $1.2 \mathrm{wt} \%$, and $\mathrm{CaO}$ from 0.3 to $0.9 \%$. Harker-type diagrams show rather continuous trends from the less-evolved Urucum facies to the more evolved tourmaline-bearing and pegmatitic facies. The behavior of several major oxides and trace elements $\left(\mathrm{Fe}_{2} \mathrm{O}_{3}\right.$, $\mathrm{MgO}, \mathrm{MnO}, \mathrm{CaO}, \mathrm{TiO}_{2}, \mathrm{Al}_{2} \mathrm{O}_{3}, \mathrm{~K} 2 \mathrm{O}, \mathrm{Rb}$ and $\mathrm{Ba}$ ) reflects the role played by fractionation of ferromagnesian minerals, feldspars and accessory minerals. Initial $\mathrm{Sr}^{87} / \mathrm{Sr}^{86}$ ratios vary from 0.711 to 0.716 , with $\varepsilon_{\mathrm{Nd}(580 \mathrm{Ma})}$ values between -7.4 to -8.2 , and $\mathrm{Sm}-\mathrm{Nd} \mathrm{T}_{\mathrm{DM}}$ model ages ranging from 2290 to $1840 \mathrm{Ma}$.
\end{abstract}

KEYWORDS: Urucum suite; Geochemistry; Petrogenesis; Araçuaí belt.
RESUMO: A suite Urucum (U/Pb em zircāo: $582 \pm 2 \mathrm{Ma}$ ), situada na regiáo do Vale do Médio Rio Doce, leste de Minas Gerais, caracteriza-se por plutons graníticos alongados (NW-SE e N-S) sin a tardi-colisionais associados à Zona de Cisalhamento de Alto Angulo de Conselho Peña-Resplendor. São rochas foliadas, com predominio da foliação no estado sólido em relação à foliação magmática. Foram caracterizadas quatro fácies: (i) porfiritica (Urucum), (ii) inequigranular média a grossa, (iii) com turmalina, e (iv) pegmatítica. Essas fácies são peraluminosas, com indice de saturaçâo em alumina entre 0,98 e 1,38. Os teores em $\mathrm{SiO}_{2}$ variam entre 70,7 e $73,7 \%$, com valores de $\mathrm{K}_{2} \mathrm{O}$ entre 3,5 e 5,7\%, $\mathrm{Na}_{2} \mathrm{O}$ entre 1,9 e 4,4\%, $\mathrm{MgO}$ entre 0,6 e 1,2\%, e CaO entre 0,3 e 0,9\%. Em diagramas tipo Harker, os dados quimicos mostram trends mais ou menos contínuos desde a fácies menos evoluida (Urucum) até fácies mais evoluidas (turmalina-granitos e pegmatítica). O comportamento de vários elementos maiores e traços $\left(\mathrm{Fe}_{2} \mathrm{O}_{3}, \mathrm{MgO}, \mathrm{Mno}, \mathrm{CaO}, \mathrm{TiO}_{2}, \mathrm{Al}_{2} \mathrm{O}_{3}, \mathrm{~K}_{2} \mathrm{O}, \mathrm{Rb}\right.$ and $B a)$ mostram a importância da cristalização fracionada de minerais ferromagnesianos, feldspatos e minerais acessórios. A razão inicial de $\mathrm{Sr}^{87}$ $S r^{86}$ varia de 0,711 a 0,716 , com $\varepsilon_{N d(580 \mathrm{Ma})}$ entre -7,4 e-8,2, e idades modelo Sm-Nd entre 2290 e $1840 \mathrm{Ma}$

PALAVRAS-CHAVE: Suite Urucum; Geoquimica; Petrogênese; Cinturão Araçuaí.

${ }^{1}$ Geology Department, Universidade Federal de Ouro Preto - UFOP, Ouro Preto (MG), Brazil. E-mail: nalini@degeo.ufop.br 2Environmental and Sedimentary Geology Department, Universidade de São Paulo - USP, São Paulo (SP), Brasil. E-mail:rmachado@usp.br 33École des Mines de Saint-Étienne, Saint-Étienne, França. E-mail: bilalessaid@gmail.com ${ }^{*}$ Autor correspondente.

Manuscrito ID: 30158. Recebido em: 08/27/2014. Aprovado em: 02/23/2015. 


\section{INTRODUCTION}

Several papers discuss the generation of significant amounts of granites by crustal melting in the late periods of crustal thickening (collision) and also the role of erosion upon the decompression melting and its effect on increasing partial melting (England \& Thompson 1984; Hollister 1993; Inger 1994). The crustal thickening is not favorable to generation of a widespread melting (England \& Thompson 1984). According to Sylvester (1998), strongly aluminous granites are formed in different types of orogens during the post-collisional phase. During the exhumation episode, which is accompanied by uplift and erosion, partial relaxation of isotherms occurs and widespread amounts of granitic melting are generated in this phase, which comes after collision (Thompson 1981; England \& Richardson 1977).

Experimental models show that crustal anatexis of rocks of different compositions is a common process in levels of middle and lower crust (Stevens \& Clemens 1993), and it takes place after collision (England \& Thompson 1984). They also reveal that widespread amounts of melt can only be generated under $\mathrm{H}_{2} 0$-saturated conditions, situation more common in upper crust. Moreover, under $\mathrm{H}_{2} 0$-undersaturated conditions, appreciable amounts of melt can only be generated as a result of dehydrations involving muscovite, biotite and hornblende (Clemens \& Vielzeuf 1987; Vielzeuf \& Holloway 198; Patińo Douce \& Beard 1995).

The $\mathrm{CaO} / \mathrm{Na}_{2} \mathrm{O}$ ratios are used to separate pelites-derived strongly peraluminous granites from sandstone-derived ones. The first tends to show values lower than 0.30 , while the second one, values higher than 0.30 (Sylvester 1998).

The studied area is located in the Mid-Rio Doce Valley, between Galileia and Conselheiro Peña municipalities, Minas Gerais State - Brazil (Fig. 1A). It belongs to the central segment of the Araçuaí Belt (sensu Pedrosa-Soares et al. 2001; Pedrosa-Soares \& Wiedemann-Leonardos 2000) or Northern Mantiqueira Province (Almeida 1984). In this internal domain (or Eastern Sector, according to Siga Jr. 1986) of the Araçuaí Belt, the regional structures strike between N-S and N-NW, stressing expressive high-angle, ductile shear zones, such as the Resplendor-Conselheiro Peña Shear Zone (Nalini 1997).

The Urucum suite granitoids, focus of this study, correspond to the most expressive peraluminous granitic magmatism of the Rio Doce Valley. They are constituted by two batholiths (of $-120 \mathrm{~km}^{2}$ and $-100 \mathrm{~km}^{2}$ ) and smaller plutons, one of $25 \mathrm{~km}^{2}$ and the others of $5 \mathrm{~km}^{2}$. The larger bodies are elongated along NW-SE and N-S, and are 17 and $5 \mathrm{~km}$ long and 2 and $1.8 \mathrm{~km}$ wide, respectively; their emplacement was controlled by the Conselheiro Peña-Resplendor high-angle shear zone (Nalini 1997, Nalini et al. 2008).
Their margins and inner parts are characterized by a foliated structure dominated by a solid-state foliation and usually by mylonitic and protomylonitic textures. The contacts with surrounding rocks are tectonic. The granites are leuco- to mesocratic and present a coarse-grained, porphyritic texture. Microcline megacrystals (up to $10 \mathrm{~cm}$-sized) represent, together with plagioclase (oligoclase), 30 to $80 \%$ in volume of the rock.

\section{THE REGIONAL CONTEXT OF THE NEOPROTEROZOIC GRANITOIDS}

Siga Jr. (1986), using $\mathrm{Rb} / \mathrm{Sr}$ and $\mathrm{U} / \mathrm{Pb}$ radiometric data, divided the Neoproterozoic granitoids of the Araçuaí belt in three groups:

1. syn- to late-tectonic $(650-550 \mathrm{Ma})$;

2. late- to post-tectonic $(550-500 \mathrm{Ma})$, and

3. post-tectonic $(500-450 \mathrm{Ma})$.

The results of the 1/100,000 scale Projeto de Levantamento Geológico Básico (PLGB - Basic Geologic Survey Project) carried out by CPRM in the Rio Doce Valley led to the classification of the granitoid massifs into three main tectonic groups related to:

1. pre- to syn-regional metamorphism;

2. syn-transcurrent faulting, and

3. post-transcurrent faulting (Féboli et al. 1993b).

The most deformed rocks were included in the first group and are concordant with the regional structures. They have expanded composition (tonalite-granodiorite-granite), of calc-alkaline and meta-aluminous geochemical characteristics, having evolved in volcanic-arc and with intraplate settings. The second group is represented by elongated, batholith- showing mylonitic and cataclastic foliation along the borders which varies inwards to an isotropic structure. The geochemical characteristics are very similar to those of the previous group, differing in the peraluminous terms and its post-collisional tectonic. Small plutons are included in the third group. They are ring- and oval-shaped, zoned and concentric, commonly associated with charnockitic, basic, intermediate and ultrabasic rocks (Aimorés, Lagoa Preta, Várzea Alegre massifs, among others). This group is characterized as I-type granites of calc-alkaline and tholeiitic affinities and with intraplate and volcanic-arc settings or related to post-orogenic and post-collisional uplift (Féboli et al. 1993, Vieira et al. 1993).

In the eastern portion of the studied area, there is located the Brasiliano Rio Doce magmatic arc developed within the 590 - 480 Ma interval (Figueiredo \& Campos Neto 1993). 
It corresponds to the same magmatic arc described by Wiedemann (1993). Figueiredo \& Campos Neto (1993) and Campos Neto \& Figueiredo (1995) divided this magmatism in pre-collisional (590 to $570 \mathrm{Ma}$ ), syn-collisional (560 to $530 \mathrm{Ma}$ ) and post-collisional (520 and $480 \mathrm{Ma}$ ), whereas Wiedemann (1993) divided it in syn-orogenic (590 to $580 \mathrm{Ma}$ ) and late- to post-orogenic (520 to $450 \mathrm{Ma}$ ).

Bilal et al. $(1998,2000)$ divided the Neoproterozoic granitic magmatism of the Rio Doce Valley in four groups:

1. pre-tectonic, represented by the Galileia suite, which yields an U/Pb age of $595 \mathrm{Ma}$;

2. syn-tectonic, represented by the Urucum suite, of 582 $\mathrm{Ma}(\mathrm{U} / \mathrm{Pb}$ age);

3. late- to post-tectonic, including the intrusive ring complexes such as Aimorés and Ibituba-Itapina, of 537 to $520 \mathrm{Ma}$; and

4. post-tectonic, represented by the Ibituruna Syenite, which yields a $\mathrm{Rb} / \mathrm{Sr}$ age of $511 \mathrm{Ma}$.

Conventional $\mathrm{U} / \mathrm{Pb}$ zircon ages of $594 \mathrm{Ma}$ and 582 Ma were also obtained respectively for the Galileia suite and the Urucum suite (Nalini 1997; Nalini et al. 2000a).

The Neoproterozoic granitic magmatism of the Araçuaí belt was divided by Pedrosa Soares et al. (1999) into five suites (G1 to G5), from the oldest to the youngest: G1- syn-tectonic suite, constituting the orogen anatectic core, with I-type gneissic batholiths; G2- calc-alkaline syn-tectonic suite, with $S$-type granitoids; G3- late-tectonic suite, with S-type peraluminous granites; G4- high-K, calc-alkaline, late- to post-tectonic suite, with I-type granites, including plutons of the charnockitic association (Aimorés, Padre do Paraíso, among others); G5post-tectonic suite, with predominance of S-type peraluminous granites in zoned plutons, with biotite-granites in the center and two-mica granites or muscovite-garnet granites at the borders. The origin of suite G1 is related to regional anatexis of metasedimentary rocks during crustal thickening, with the generation of suite G3 during the late stage of the process. Suites G2 and G4 are related to the successive stages of a continental magmatic arc evolution. Suite G2 represents the arc root, linked to a subduction zone dipping eastwards (Pedrosa Soares et al. 1998, 1999), whereas G4, generated at deep crustal levels, is related to crust/mantle interactions. Suite G5, emplaced at shallower levels (6 to $12 \mathrm{~km}$ ), was generated in parts of a thickened crust (Pedrosa Soares et al. 1987, 1999). Later, Pedrosa Soares and Wiedemann-Leonardos (2000) considered the suite G2 (now named G1) older than suite G1 (now named G2), characterizing the first one as pre-collisional (between 625and $595 \mathrm{Ma}$ ) and the latter as syn-collisional (between 595 and $575 \mathrm{Ma}$ ).
The collection of geochronological data is still not sufficient for good interpretations regarding the Araçuaí Belt Brasiliano granites. $\mathrm{Pb} / \mathrm{Pb}$ dating (of zircon by the evaporation method) carried out for six plutons (and a granitic vein) of suites G1, G2 and G5 defined the following ages: G1/ G2- $591 \pm 4 \mathrm{Ma}$ (Ataléia); $582 \pm 5 \mathrm{Ma}$ (Wolf), $595 \pm 3 \mathrm{Ma}$ (Brasilândia); $575 \pm 2 \mathrm{Ma}$ (Guarataia); $576 \pm 5$ Ma (São Vitor/ Pescador); G5- $519 \pm 2 \mathrm{Ma}$ (Caladão/Padre Paraíso), and $503 \pm 9 \mathrm{Ma}$ (granitic veins crosscutting the Caladão Pluton) (Noce et al. 1999; Noce et al. 2000).

The original scheme of Pedrosa Soares et al. (1999) was modified by Pedrosa Soares et al. (2001). The granitoids from Araçuaí belt of group 3 were subdivided into G3I and G3S. The first group is characterized by calc-alkaline magma emplaced along oblique to strike-slip shear zones. The second group has peraluminous signature and consists of a series of small coalesced or isoled sillimanite-cordierite-garnet leocogranitic bodies (Pedrosa Soares et al. 2001). Later, Pedrosa Soares et al. (2008) returned to the groups and, more recently, designated them as supersuites (Pedrosa Soares et al. 2011).

\section{THE URUCUM GRANITIC SUITE}

Barbosa et al. (1964) used for the first time the term "Urucum" to name the two-mica granites of the Urucum ridge, east of Galileia. Later, Silva et al. (1987) defined the Urucum suite, including the Urucum Granite, the Palmital Granodiorite (Barbosa et al. 1964) and associated pegmatites. They also describe xenoliths of São Tomé Group schists and suggest an origin of this granites by melting epi- to mesozonal of the base of this group and of their lower units (Crenaque Group) and of part of the Pocrane Complex.

The Urucum suite in Minas Gerais occupies about $250 \mathrm{~km}^{2}$. It consists of three main plutons:

1. Urucum (porphyritic facies),

2. Palmital (inequigranular facies) and

3. Tourmaline granite (tourmaline-bearing facies).

These plutons are elongated (Palmital) and rounded (Urucum), and oriented in direction NW-SE and N-S. They are foliated, especially at its borders and in the vicinity of shear zones and host rocks. The foliations are steep- to vertical-dipping (Fig. 1b). These plutons are located in the central part of a NW-trending brachyanticlinal structure, located east of Galileia (Moura et al. 1978b, Issa Filho et al. 1980). Their emplacement is associated with the Conselho PeñaResplendor Shear corridor (Nalini 1997, Nalini et al. 2008).

The rocks of Urucum suite are characterized by the foliations developed in solid and magmatic states, related to 

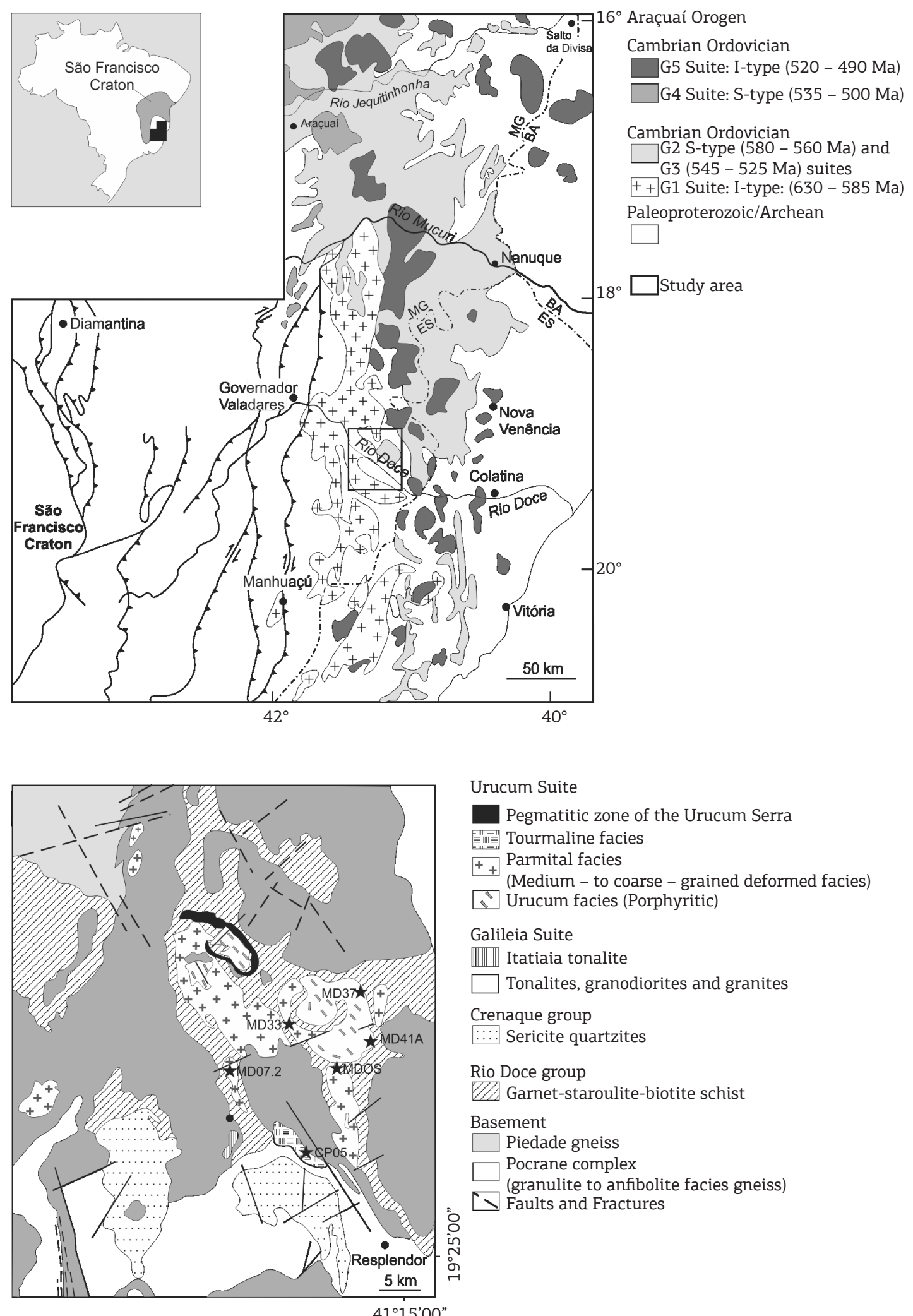

Urucum Suite

Pegmatitic zone of the Urucum Serra Fin= $=$ Tourmaline facies

+ Parmital facies

(Medium - to coarse - grained deformed facies)

$\$$ Urucum facies (Porphyritic)

Galileia Suite

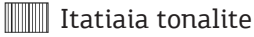

$\square$ Tonalites, granodiorites and granites

Crenaque group

$\therefore:$ Sericite quartzites

\section{Rio Doce group}

$\mathbb{Z}$ Garnet-staroulite-biotite schist

Basement

$\square$ Piedade gneiss

Pocrane complex

(granulite to anfibolite facies gneiss)

$\checkmark$ Faults and Fractures

\&

กับ

$41^{\circ} 15^{\prime} 00^{\prime \prime}$

Figure 1. (A) Simplified geological map of the Araçuaí orogen and adjacent regions of the São Francisco Craton (modified from Pedrosa-Soares et al. 2007 and 2008). (B) Geologic map of the study area (modified from Silva et al. 1987, Barbosa et al. 1964 and Nalini 1997). 
the first regional deformation phase $\left(D_{1}\right)$. This phase is also recorded in the São Tomé Formation schists (Sn-foliation) (Nalini 1997, Nalini et al. 2008). The metamorphic assemblage of these rocks (staurolite and almandine) suggests metamorphism of lower amphibolite-facies, that occurred under the following conditions: $\mathrm{P}$ - about $4-5 \mathrm{kbar}$, and $\mathrm{T}$ ranging from 500 to $600^{\circ} \mathrm{C}$ (Nalini 1997). In this sense, the emplacement of the Urucum Suite is considered syn-tectonic with respect to $D_{1}$ - phase, and its generation is related to a regional metamorphic event that affected the above schists and that took place during crustal thickening (Nalini 1997).

In the Rio Doce Valley, peraluminous granites (S-type) are associated with pegmatitic bodies, being well-known the Marilac of Galilelia-Conselheiro Peña pegmatitic fields (Correia Neves et al. 1986). The Marilac pegmatitic field, situated northwest of the Governador Valadares city, is $30-40 \mathrm{~km}$ wide and stretches out for $90-100 \mathrm{~km}$ along an approximate N-S direction.

The Conselheiro Peña-Galileia pegmatitic field, situated east of Governador Valadares, is $35-45 \mathrm{~km}$ wide and stretches out for $100 \mathrm{~km}$ along an approximate $\mathrm{N}$ - direction. These pegmatites are emplaced in garnet- and staurolite mica-schists of the São Tomé Group and in Neoproterozoic granitoids of the Galileia and Urucum suites.

\section{Petrography}

The Urucum suite is constituted by four main facies:

1. porphyritic (Urucum facies),

2. medium- to coarse inequigranular (Palmital facies),

3. tourmaline-bearing, and

4. pegmatitic facies.

The predominant facies are the first two (Fig. 1b). The tourmaline-bearing facies can constitute bodies of up to $15 \mathrm{~km}^{2}$, as one that occurs in the southeastern region of Conselheiro Peña. These granites are less deformed than those of the Palmital facies and are emplaced in quartzites of the Crenaque Group (Nalini 1997). Their texture is granular, and the rock-forming minerals are biotite, muscovite, potassic feldspar (microcline and orthoclase) and plagioclase. The accessory minerals are apatite, garnet, zircon, monazite and tourmaline.

The Urucum and Palmital facies show transitional contact between them. It is marked by increasing of potassic feldspar megacrystals toward Urucum facies, with the texture passing of inequigranular to porphyritic. Centimeter-sized ( 6 to $8 \mathrm{~cm}$ ) potassic feldspar megacrystals (microcline) are common in this facies. Essential minerals are plagioclase and potassic feldspar ( $50-70 \%$ of rock volume), with variable quartz, muscovite and biotite contents. Plagioclase crystals rimmed by albite are included in potassic feldspar megacrystals. Frequent accessory minerals are garnet, tourmaline, ilmenite and apatite. Feldspar megacrystals are usually aligned and possibly define a magmatic foliation. In the vicinity of shear zones occurs solide-state deformation observed under the microscope, being commom protomylonitic texture with potassic feldspar porphyroclasts involved by a finer matrix showing composed of recrystallized quartz, plagioclase, mica and microcline together with an expressive amount of myrmekite.

Two types of plagioclase are distinguished: euhedral to sub-euhedral, poikilitic (millimeter- to centimeter-sized) megacrystals with muscovite, biotite, quartz and microcline inclusions, and sub-euhedral crystals that compose the matrix. Usually, the latter contains mineral inclusions, but in smaller amounts than the first one. The first type of plagioclase also occurs as inclusions or surrounding potassic feldspar megacrystals. An albite reaction rim is also observed, in the subhedral plagioclase grains.

The microcline is more common than orthoclase. It occurs mainly in the matrix, being rare as megacrystal. They are anhedral to sub-euhedral and exhibit characteristic geminations, and contain mica, quartz and albite-rimmed plagioclase inclusions. Microcline usually occurs as interstitial crystals or develops along plagioclase fractures.

Quartz is either strongly recrystallized or occurs as hexagon-shaped, euhedral crystals with triple junctions and also as tear drop-shaped inclusions in micas and feldspars. Euhedral to sub-euhedral, reddish brown biotite crystals present varied sizes and frequently occur in clusters, forming cummulatic textures.

Muscovite occurs in some Urucum suite granites and, with biotite, defines the foliation of the rock. Two types of muscovite are distinguished: primary and secondary. The first type is present as phase essential mineral $(5-10 \%)$ and contains inclusions of quartz, zircon and monazite. The second type is less abundant than first and lies along the cleavage planes of plagioclase (either megacrystals or crystals of the matrix) or potassic feldspar.

Millimeter-sized apatite is the most abundant accessory mineral and commonly occurs as inclusion in biotite.

\section{Geochemistry}

Twenty five representative samples of all compositions, textures and grain size of the Urucum suite were selected for whole-rock analysis (major and trace elements), 8 being from the porphyritic (Urucum) facies, 12 from the medium- to coarse inequigranular (Palmital) facies, 2 from the tourmaline-bearing facies, 2 from the pegmatitic facies, and 1 from the aplitic vein that crosscuts the other facies.

The samples were selected so as to represent the whole range of textures, compositions and grain-sizes of each facies. Special attention was given to samples that showed, under the microscope, cummulatic features, defined by both ferromagnesian minerals and feldspars, or even accessory minerals as apatite, zircon etc. Attention was also given to samples that showed some indication of fluid-phase interaction, either 
as incipient alteration of feldspars, biotite or amphibole, mainly related to silicification, albitization or greisenization.

The chemical analyses were carried out at the Geochemistry Laboratory of the Saint-Etienne School of Mines, France. The precision of the results was ensured by comparison/control with certified international standards, simultaneously analyzed with each group of samples.

The data were obtained by X-ray fluorescence spectrometry model PW 1404 Philips spectrometer and ICP (Induced Coupled Plasma) emission spectrometry, model JY38PI + JY32P spectrometer.

The major-element analysis carried out by X-ray fluorescence and ICP methods, enabling the comparison between results and/or their use as complementary analytical methods. Major elements are very accurate by ICP and were perfomed for $\mathrm{MgO}, \mathrm{MnO}, \mathrm{CaO}$ and $\mathrm{TiO}_{2}$, considering that the contents of such components are rather low for the more evolved granites.

\section{Characterization of the Urucum Suite granitoids}

The leucogranites of Urucum suite are characterized by plot mainly in the granite and adamellite fields of the chemical-mineralogical diagram of Debon \& Le Fort (1983), and follow a trend that approaches the calc-alkaline trend defined by these authors (Fig. 2A).

In Figure 2B, the analyzed samples define two fields in the domain of the peraluminous two-mica granites: one representing the predominance of muscovite over biotite (field I), and another, the predominance of biotite over muscovite (field II). The peraluminous character of these rocks is attested by the alumina saturation diagram (A/CNK vs. A/NK, Fig. 2C); the index values fall in the $0.98-1.38$ interval, with an average of 1.13 . These values are compatible with the interval defined by Chappell \& White (1992) for Australian S-type granites $(1.01-1.39)$.

The peraluminous character of the Urucum suite granitoids is expressed by the presence of muscovite, garnet and tourmaline as the primary mineral assemblage, as well as by the presence of normative corindon (up to $4.7 \%$ ).

The $\mathrm{CaO} / \mathrm{Na}_{2} \mathrm{O}$ ratios of the different facies of studied suite are equal to 0.28 . This value is within the range of pelitic-derivated sequences post-collisional strongly peraluminous granites (Sylvester 1998).

\section{The behavior of major elements}

To study the element behavior during the crystallization process, the sum $\mathrm{Fe}_{2} \mathrm{O}_{3} \mathrm{t}+\mathrm{MgO}+\mathrm{MnO}+\mathrm{TiO}_{2}$ (FMMT), which well discriminates the different facies, was used as a differentiation index.
In general, an increase in $\mathrm{SiO}_{2}$ occurs with the decrease of FMMT during the differentiation process of the magma (Figs. $2 \mathrm{D}$ and $3 \mathrm{~A})$. This behavior suggests the fractionation of biotite, tourmaline and garnet. The $\mathrm{MgO} / \mathrm{TiO}_{2}$ ratio varies from 2.14 to 5.33, being higher than that for the I-type granitoids (Galileia suite: varies from 2.25 to 3.45 ), suggesting that the rocks studied here were originated from melting of metapelitic sequences.

Sample MD 29 (Fig. 2D) has a relatively higher $\mathrm{SiO}_{2}$ content (73\%), despite relatively high $\mathrm{MgO}(0.75 \%)$ and low $\mathrm{Na}_{2} \mathrm{O}$ contents $(1.8 \%)$ (Figs. 3D and 3F). This behavior strongly suggests that changes in composition were resultant from greisenization.

The same diagram shows that one sample of the tourmaline-bearing facies contrast from the others, yielding relatively lower $\mathrm{SiO}_{2}$ contents (71.9\%). Sample MD07.2 is more $\mathrm{Al}_{2} \mathrm{O}_{3}, \mathrm{CaO}$ and $\mathrm{Na}_{2} \mathrm{O}$ enriched than CP05A (15.1, 1.6 and $4.3 \%$ versus $13.7,1.1$ and $3.8 \%$, respectively). One of the samples (CP05A) has significant tourmaline content.

The ternary diagrams, including alkaline and earth alkaline metals, alumina and total ferromagnesian minerals $\left(\mathrm{CaO}-\mathrm{Al}_{2} \mathrm{O}_{3}-\mathrm{FMMT}\right)$, show the variation and mobility of these elements (Fig. 3B).

This diagram shows plagioclase enrichment for most of the granite samples of the Palmital facies (Fig. 3B). These samples show depletion of $\mathrm{P}_{2} \mathrm{O}_{5}(<0.16 \%)$ (Fig. 3C) and $\mathrm{MnO}$ (Fig. 3D). In general, an increase in $\mathrm{MnO} /\left(\mathrm{MnO}+\mathrm{Fe}_{2} \mathrm{O}_{\mathrm{t}}\right)$ values is observed from the Urucum suite granites to the pegmatites (Fig. 3D). This explains the importance of garnet crystallization in the more evolved (pegmatitic and tourmaline-bearing) facies.

The diagram (Fig. 3F) show a wide dispersion of total alkalis contents. This behavior may be explained by wide variation in the content of potassic feldspar megacrystals in the outcrop scale. $\mathrm{Al}_{2} \mathrm{O}_{3}$ and total alkalis contents increase from the Urucum facies to the pegmatitic facies (Fig. 3B). The Urucum suite leucogranites are relatively more $\mathrm{Na}_{2} \mathrm{O}$ enriched than the Himalayan Manaslu leucogranites (Vidal et al. 1984) (Fig. 3F).

\section{The behavior of trace elements}

The contents of transition elements (Co, V, Zn, Ga, Ni and $\mathrm{Cr}$ ) decrease with differentiation, exhibiting steeper gradients for $\mathrm{V}$, Co and $\mathrm{Ni}$, but a less steep gradient for $\mathrm{Ga}$ (Fig. 4). Most of the tourmaline-bearing samples are depleted in transition elements, which reflect the lower incorporation of such elements.

The dispersion of $\mathrm{Rb}$ (between 121 and $262 \mathrm{ppm}$ ) and $\mathrm{Ba}(<500 \mathrm{ppm})$ contents results from the crystallization of potassic feldspar megacrystals. On the other hand, the increase of $\mathrm{Ba} / \mathrm{Sr}$ values (excepting for microgranites) reflects plagioclase crystallization (Fig. 3E). 
Despite the dispersion seen in Figure 5A, Th contents decrease with the evolution from the Urucum granite to the pegmatites. Some Palmital (MD60-22.6 ppm; MD59- 15.7 ppm; MD79- 14.1 ppm) and Urucum (MD56- 20.5 ppm) granite samples are relatively more Th enriched, probably due to their higher monazite content, which explains why they do not plot in main trend. The Th/ $\mathrm{U}$ ratio, between 0.30 and 4.33 , is relatively low when compared to the usual values (from 3 to 5) yielded by granitic rocks (Fourcade 1981), but are comparable with the values obtained by Cuney et al. (1984) for the Himalayan Manaslu leucogranites $(0.2<\mathrm{Th} / \mathrm{U}<8)$. This ratio is controlled by monazite extraction, and the resulting fractionation effect has been used to explain the low values found for the Himalayan leucogranites (Vidal et al. 1984).
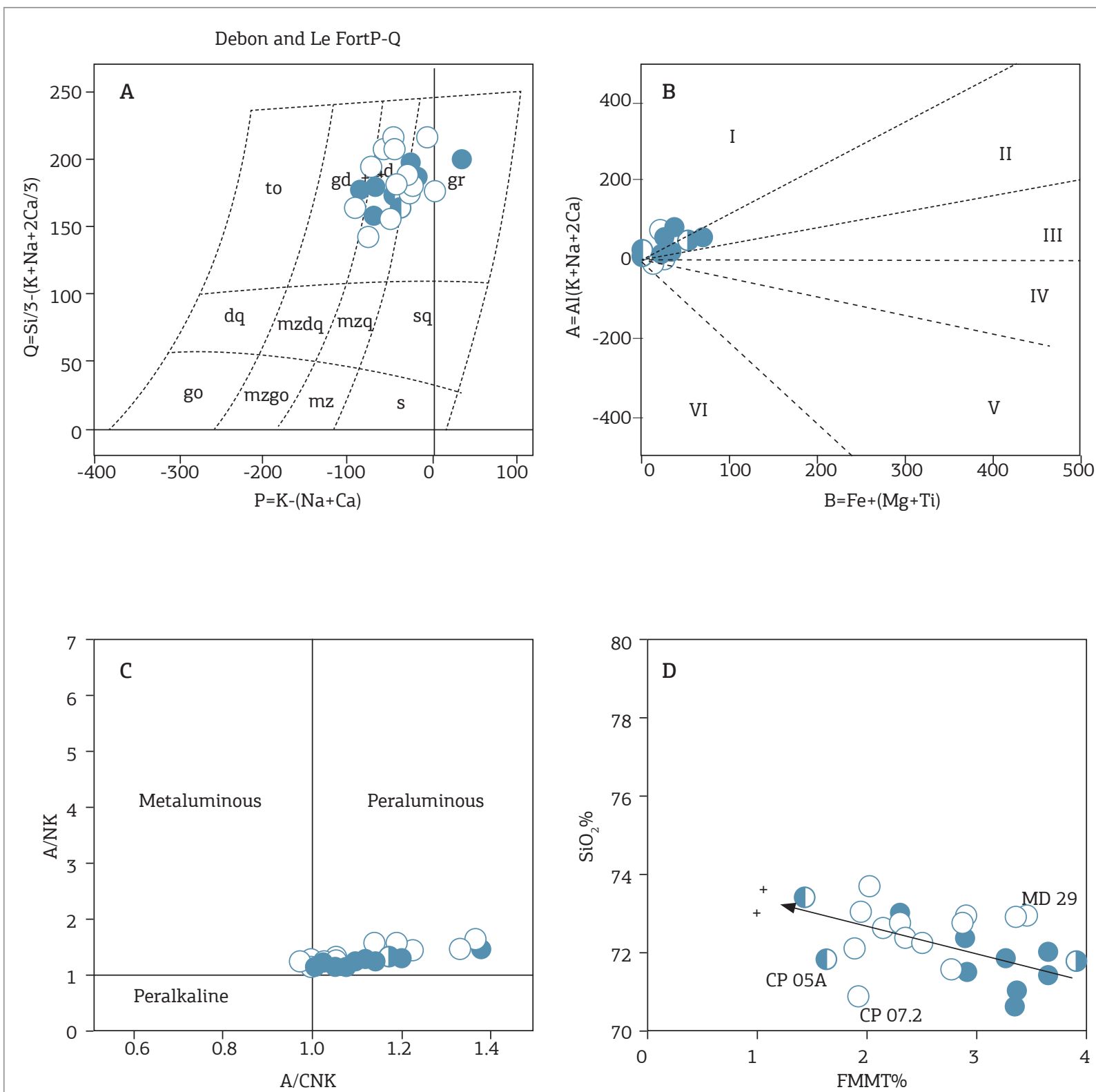

Symbols: (+) Pegmatitic Granite; Tourmaline granite; $\bigcirc$ Palmital Granite; U Urucum Granite; $\bigcirc$ Vein of granite.

Figure 2. Distribution of granitic facies of Urucum suite based on the diagrams: (A and B) quimical-mineralogical ( $Q$ versus $\mathrm{P}$ ) and (A versus $\mathrm{B}$ ) of Debon \& Le Fort (1983); with the last classification being divided into the following types of granites: I - peraluminous with two-mica (muscovite > biotite), II - peraluminous with biotite $>$ muscovite, III - peraluminous with biotite; IV - metaluminous with biotite \pm amphibole \pm ortopyroxene \pm clinopyroxene; V exceptional rocks as carbonatites etc., and VI - leucogranites; (C) Shand's index (Maniar and Piccoli 1989), and (D) the sum $\mathrm{Fe}_{2} \mathrm{O}_{3}{ }^{\mathrm{t}}+\mathrm{MgO}+\mathrm{MnO}+\mathrm{TiO}_{2}(\mathrm{FMMT})$ versus $\mathrm{SiO}_{2}$. 

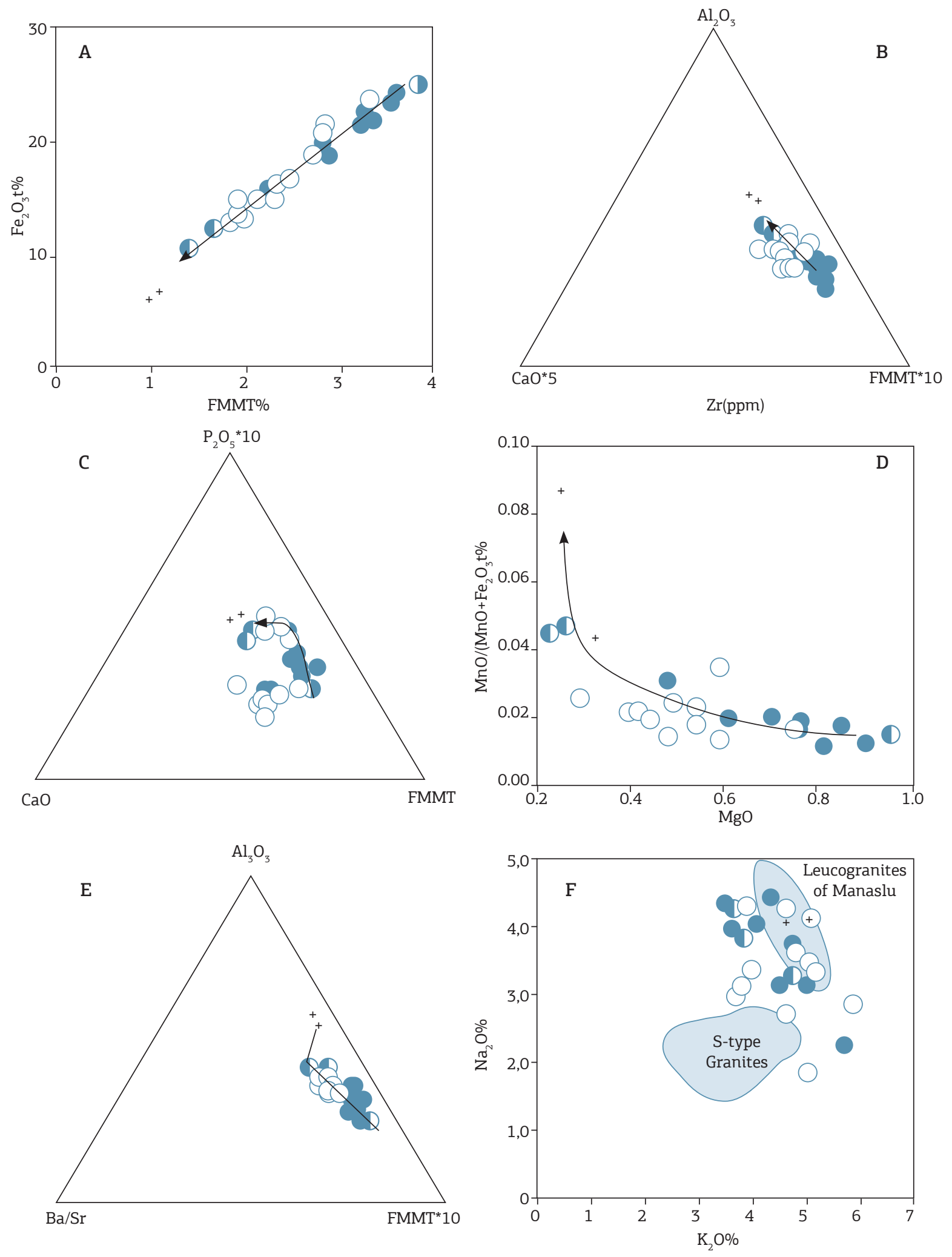

Symbols: (+) Pegmatitic Granite; Tourmaline granite; $\bigcirc$ Palmital Granite; Urucum Granite; Vein of granite.

Figure 3. Distribution of granitic facies of Urucum suite based on the diagrams: (A) CaO $5-\mathrm{Al}_{2} \mathrm{O}_{3}-\mathrm{FMMT}^{*} 10\left(\mathrm{Fe}_{2} \mathrm{O}_{3}{ }^{\mathrm{t}}\right.$

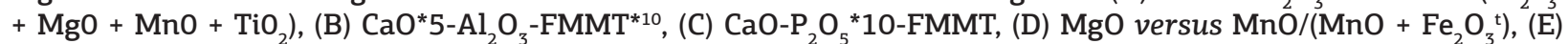
$\mathrm{Ba} / \mathrm{Sr}-\mathrm{Al}_{2} \mathrm{O}_{3}-\mathrm{FMMT}^{* 10}$, (F) $\mathrm{K}_{2} \mathrm{O}$ versus $\mathrm{Na}_{2} \mathrm{O}$. 

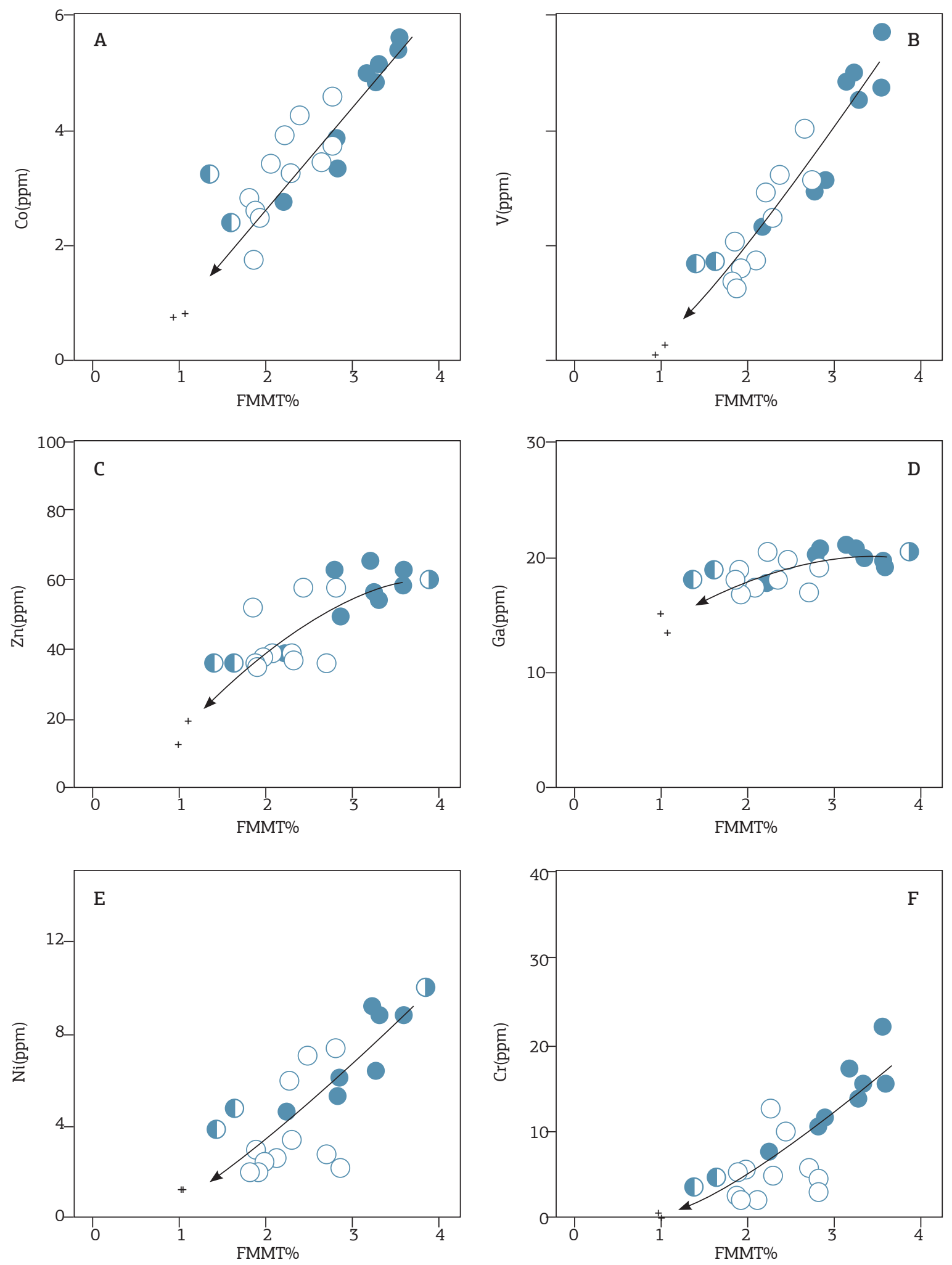

Symbols: (+) Pegmatitic Granite; Tourmaline granite; $\bigcirc$ Palmital Granite; $\bullet$ Urucum Granite; $\bigcirc$ Vein of granite.

Figure 4. Distribution of granitic facies of Urucum suite based on the diagram with trace elements. 

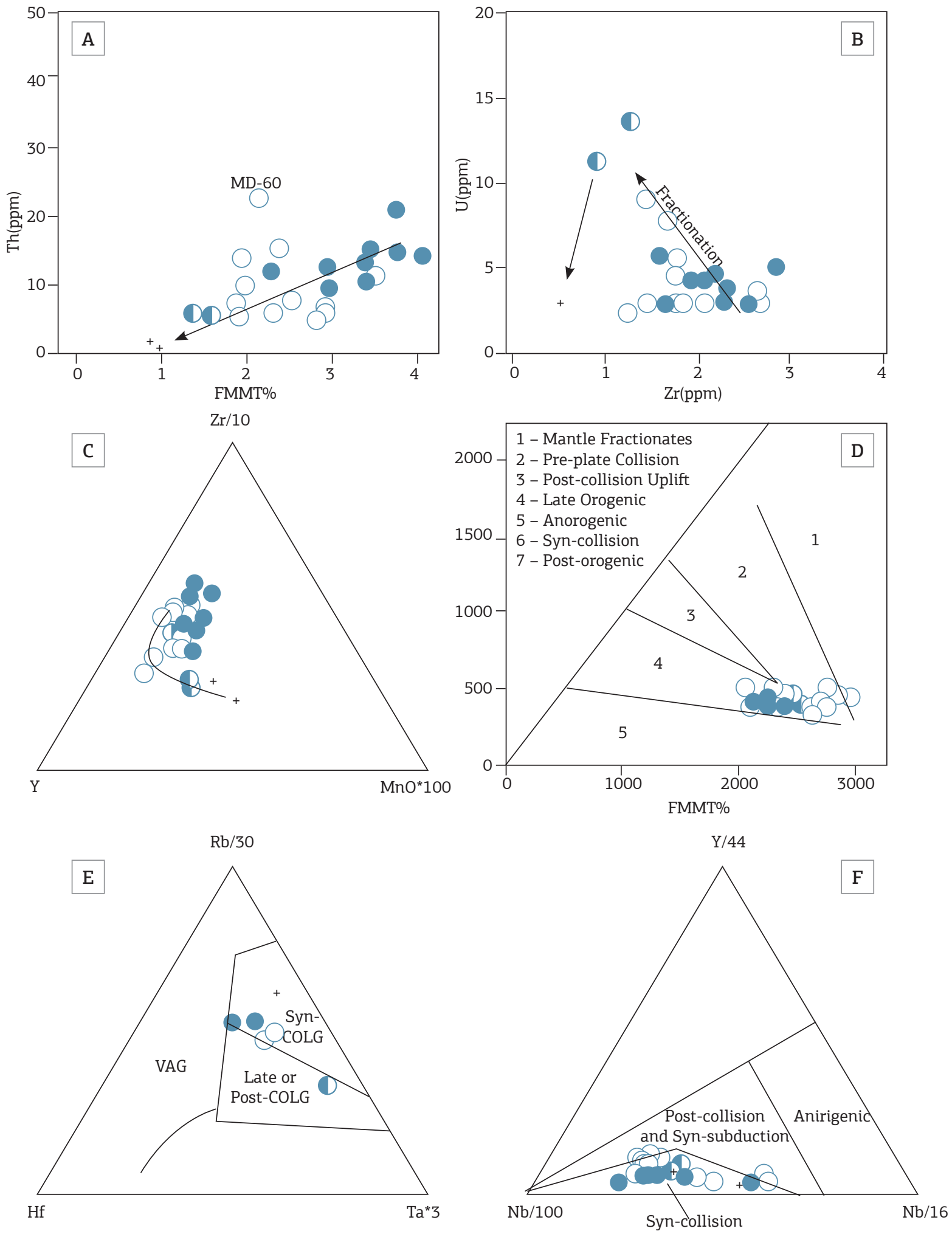

Symbols: (+) Pegmatitic Granite; Tourmaline granite; $\bigcirc$ Palmital Granite; $\bigcirc$ Urucum Granite; $\bigcirc$ Vein of granite.

Figure 5. Distribution of granitic facies of Urucum suite based on the diagrams: (A) FMMT-Th, (B) Zr versus U), (C) Y-Zr/10-Mn O ${ }^{* 100}$, (D) Batchelor \& Bowden (1985), (E) Harris et al. (1994) and (F) Thièblemont \& Cabanis (1990). 


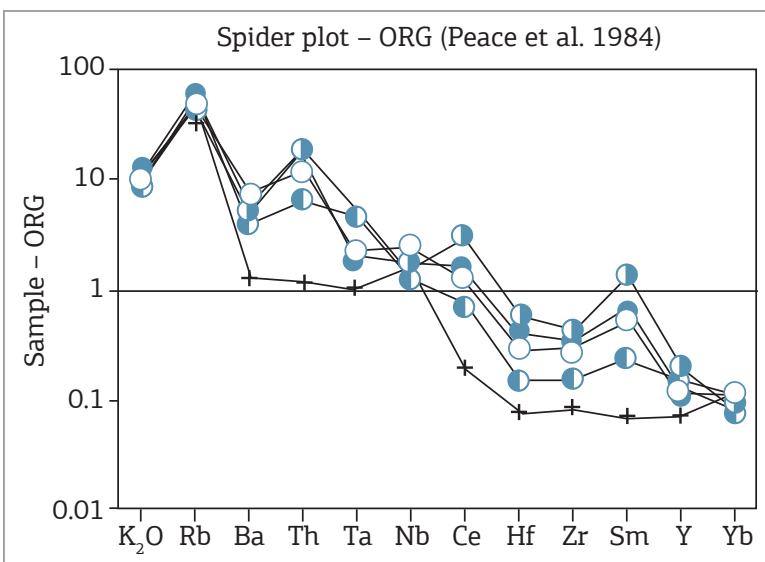

Symbols: (+) Pegmatitic Granite; $\bigcirc$ Tourmaline granite; $\bigcirc$ Palmital Granite; Urucum Granite; Vein of granite.

Figure 6. Distribution patterns of the granitic facies of Urucum suite based on the multi- normalized element diagram to mid-oceanic ridge granites of Pearce et al. (1984).

In general, the solubility of zircon decreases with temperature, while magma acidity and the peraluminous character increase (Watson 1979; Harrison \& Watson 1983; Watson $\&$ Harrison 1984). However, the saturation level depends strongly upon molar $\left.\left(\mathrm{Na}_{2} \mathrm{O}+\mathrm{K}_{2} \mathrm{O}\right) / \mathrm{Al}_{2} \mathrm{O}_{3}\right)$ of the melts, with remarkably little sensitivity to temperature, $\mathrm{SiO}_{2}$ concentration, or melt $\mathrm{Na}_{2} \mathrm{O} / \mathrm{K}_{2} \mathrm{O}$. Watson (1979) experiments show that in peraluminous melts and melts lying in the quartz-orthoclase-albite composition plane, less than $100 \mathrm{ppm} \mathrm{Zr}$ is required for zircon saturation. The mains conclusion of author is that any felsic, no-peralkaline magma is likely to contain zircons crystals, because the saturation level is so low for these compositions.

$\mathrm{Zr}$ contents decrease with differentiation and show negative correlation with $\mathrm{U}$ (except for pegmatites) (Fig.5B), showing that at the last stages of the magmatic crystallization $\mathrm{U}$ behaves as an incompatible element, thus leading to $U$ enrichment in the residual liquids, fact confirmed by the presence of $U$ minerals in the pegmatites.

$\mathrm{Y}$ contents are controlled by zircon in the less evolved facies (Urucum and Palmital granites) and by garnet in the more evolved facies (tourmaline-bearing granites and pegmatites) (Fig.5C).

\section{Discrimination diagrams for tectonic settings}

The composition of the Urucum suite granitoids is comparable to that of syn-collisional granites of Batchelor \& Bowden (1985) (Fig. 5D). This observation is confirmed by the Rb/30-Hf-Ta*3 diagram of Harris et al. (1994) (Fig. $5 \mathrm{E}$ ) and the $\mathrm{Y} / 44-\mathrm{Rb} / 100-\mathrm{Nb} / 16$ diagram of Thiéblemont and Cabanis (1990) (Fig.5F). These parameters indicate that the composition of Urucum suite is similar to that of syn-collisional granites described by those authors. Ta contents (determined by neutron activation) increase from the Urucum to the tourmaline-bearing facies and then decrease to the pegmatitic granite, indicating that during the crystallization of the latter Ta behaved as an incompatible element. Ta enrichment in the residual pegmatitic liquid is confirmed by the crystallization of niobium tantalates in the pegmatites.

In the multi-element diagrams of Fig. 6 (values normalized to mid-ocean ridge granites of Pearce et al. 1984), a similar behavior is observed for the Palmital, Urucum and tourmaline-bearing facies. These facies altogether present enrichment in large-ion lithophile elements (LILE), $\mathrm{K}_{2} \mathrm{O}, \mathrm{Rb}$ and $\mathrm{Ba}$. Additionally, positive $\mathrm{Rb}, \mathrm{Th}, \mathrm{Nb}$ and $\mathrm{Sm}$ anomalies are observed. The relatively high $\mathrm{Rb}$ values are typical of syn-collisional granites, implicating an important fluid phase (Pearce et al. 1984). The high $\mathrm{Rb}$ contents of these granites are in many cases because they are derived from melting of metapelites. Negative anomalies result for $\mathrm{Ba}, \mathrm{Ta}, \mathrm{Hf}, \mathrm{Zr}$ and $\mathrm{Yb}$.

The pegmatitic granites behave in a relatively distinct way. These feldspar-rich rocks show positive $\mathrm{Rb}$ and $\mathrm{Nb}$ anomalies. On the other hand, the values for elements such as $\mathrm{Ba}$, Th and $\mathrm{Ta}$ approach those for oceanic-ridge granites, whereas $\mathrm{Ce}, \mathrm{Hf}, \mathrm{Zr}, \mathrm{Sm}, \mathrm{Y}$ and $\mathrm{Yb}$ show values around 0.1 times the normalization values (Fig.6).

\section{DISCUSSION}

The Urucum suite is characterized by peraluminous granitoids whose alumina saturation index is comparable to those for the Australian S-type granites (Chappell \& White 1974). However, the Urucum suite granites are more $\mathrm{Na}_{2} \mathrm{O}$ enriched (average 3.5 versus $2.5 \%$ ) and more $\mathrm{MgO}$ and $\mathrm{CaO}$ depleted (average 0.58 and $1.0 \%$ versus 1.0 and $1.7 \%$, respectively) than the average $\mathrm{S}$-type granites (Chappell \& White 1992). The $\mathrm{CaO} / \mathrm{Na}_{2} \mathrm{O}$ ratios (0.28) are compatible with derivated-pelitic sequences peraluminous granites (Sylvester 1998). The composition of the Urucum suite granitoids is comparable, nevertheless, to that of the syn-collisional granites (Nalini et al. 2000b).

Harker-type diagrams show more or less continuous trends from the (less evolved) Urucum to the (more evolved) tourmaline-bearing and pegmatitic facies, which puts in evidence the fractionation by ferromagnesian minerals, feldspars and accessory minerals during the crystallization of the Urucum suite granitoids. On the other hand, the dispersion illustrated in the alkaline metal diagrams is compatible with crystallization of potassic feldspar as important cummulatic phase, particularly in the pegmatitic facies. $\mathrm{Al}_{2} \mathrm{O}_{3}$ enrichment also takes place, as suggested by the petrographic observations. 
The decrease in transition elements and concentrations (Fig. 4) during magma evolution is due to biotite, tourmaline and garnet fractionation.

Isotopic data available for the Urucum suite (six samples) yield initial $\mathrm{Sr}^{87} / \mathrm{Sr}^{86}$ ratios in the $0.711-0.716$ interval, and $\varepsilon_{\mathrm{Nd}(580 \mathrm{Ma})}$ values between -7.4 and -8.2 , what are compatible with a magma produced by crustal melting of the pelitic sedimentary sequences (Nalini 1997, Nalini et al. 2000a). Model ages calculated according to depleted mantle (De Paolo 1981) and obtained for six Urucum suite samples yielded ages in the $1840-2290 \mathrm{Ma}$ interval, which is confirmed by inherited zircon $\mathrm{U} / \mathrm{Pb}$ ages of $2000 \pm 300$ $\mathrm{Ma}$, suggesting the involvement of Paleoproterozoic protoliths in the origin of the Urucum suite (Nalini et al. 2000a).

Geothermometric data were obtained by three methods: 1. apatite and zircon saturation (Watson \& Harrison 1984),

2. content of light rare earth in granitic liquids (Montel 1986), and

3. substitution in mica (Monier \& Robert 1986).

These results indicate crystallization temperatures in the range of $700-750^{\circ} \mathrm{C}$ for the Urucum and Palmital facies, from $650-700^{\circ} \mathrm{C}$ for the tourmaline-bearing facies, and about $600-650^{\circ} \mathrm{C}$ for the pegmatitic facies (Nalini 1997). As previously mentioned, barometric data suggest minimum pressure conditions around 4 kbar (Nalini 1997).

The comparison of the data presented here with those available in the literature shows that the age for the granitoids of the Urucum suite $(582 \mathrm{Ma})$ falls in the interval of the syn-collisional magmatism of the Araçuaí Orogeny (595 and $575 \mathrm{Ma}$ ) and of the Ribeira belt (600 to 590/570 and even 560/540 Ma) in Rio de Janeiro State, respectively (Heilbron et al. 1995 and 2004; Machado et al. 1996; Machado 1997; Machado \& Demange 1998; Trouw et al. 2000; Heilbron \& Machado 2003; Silva et al. 2003; Pedrosa-Soares et al. 1999, 2001, 2008; Pedrosa-Soares \&Wiedemann-Leonardos 2000), and correspond to the same range of pre-collisional magmatism of the Rio Doce arc/orogeny (Figueiredo \& Campos Neto 1993; Campos Neto \& Figueiredo 1995).

\section{CONCLUSIONS}

During the interpretation of the Urucum suite geochemical data, a strong relation between the evolution of (major and trace) elements and the fractional crystallization of feldspars, ferromagnesian and accessory minerals was stressed out. The accumulation of alkaline feldspar Urucum and pegmatitic facies was not confirmed in the diagrams using $\mathrm{K}$.

As a whole, the different facies define an evolution in the following sequence: Urucum suite granites, Palmital granite, tourmaline-bearing granite and pegmatitic granites. Thus, the fractional crystallization can be explained on the basis of variations exhibited by the major and trace element variation diagrams, in which the behavior of compatible elements, such as $\mathrm{Mg}, \mathrm{Ti}, \mathrm{Fe}, \mathrm{Ba}, \mathrm{Zr}$, Th, Co, V, Zn, Ga, Ni and $\mathrm{Cr}$, is explained by the conspicuous biotite fractionation. On the other hand, alkalies, Mn, P, Li, Ta, U and B show incompatible behavior during magma evolution.

The tourmaline crystallization (tourmaline-bearing facies) is compatible with fractional crystallization of the essential minerals and biotite presents in the magma and progressive $\mathrm{B}$ enrichment in the residual magma. However, the crystallization of small quantities of tourmaline as observed in the Urucum suite tourmaline facies (usually $<1-2 \%$ ) is not enough to significantly deplete the residual liquid in B (Pichavant 1981). This fact is confirmed by the extensive presence of tourmaline in the rare element-bearing pegmatites associated with the granites.

Geothermobarometric data available for the Urucum suite suggest crystallization under conditions temperatures varying between 750 (Urucum and Palmital facies) and $600^{\circ} \mathrm{C}$ (pegmatitic facies), and minimum pressures around $4-5 \mathrm{kbar}$ (or 12 - $15 \mathrm{~km}$ depths) (Nalini 1997). These data are compatible with the behavior showed by major and trace element diagrams.

$\mathrm{Sr}$ and $\mathrm{Nd}$ isotopic data available for the Urucum suite granitoids are similar to those obtained for syn-collisional granites (suite $\mathrm{G}_{2}$ of Pedrosa-Soares \& Wiedemann-Leonardos 2000) of the northern portion of the Araçuaí belt (Martins 2000, Martins et al. 2004), thus stressing out a strong crustal contribution during the generation of these rocks. The high initial isotopic ratios yielded by the four facies of the Urucum suite $(0.7465$ - isochron value, or from 0.7114 to $0.7165-$ individual samples), which correspond to strongly negative $\varepsilon_{\mathrm{Nd}(580 \mathrm{Ma})}$ values (between -7.4 and -8.2), are compatible with a wide partial melting of pelitic sequences to generation of its magmatism. The relative coherence of $\mathrm{T}_{\mathrm{DM}}$ model ages from $1.8 \mathrm{Ga}$ to $2.3 \mathrm{Ga}$, obtained for all facies, with the inherited zircon ages around $2.2 \mathrm{Ga}$, also suggesting melting of sediment derived from Paleoproterozoic rocks as probable sources of magma generation. This interpretation implicates a crustal residence of $c a$. 1.5 Ga for the granite protolith(s).

From the exposed above, the Urucum suite granites $(\mathrm{U} / \mathrm{Pb}$ age of $582 \mathrm{Ma})$ are ( -30 to $40 \mathrm{Ma}$ ) older than the syn-collisional granites (ages between 560 and $530 \mathrm{Ma}$ ) of the Rio Doce magmatic arc. Alternatively, they correspond to the syn-collisional magmatism (ages between 591 and $575 \mathrm{Ma}$ ) of the Araçuaí belt and also to the syn-collisional magmatism (ages between 600 and 590/570 Ma) of the Ribeira belt in Rio de Janeiro State.

The existence of S-type granites (Urucum suite) with (U-Pb zircon ages of $582 \pm 2 \mathrm{Ma}$ (Palmital facies) and $573 \pm 4 \mathrm{Ma}$ (megaporphyritic facies) suggests an interval of about 10 Ma between the end of the I-type calc-alkaline magmatism 
(Galileia suite, U-Pb age of $594 \pm 6 \mathrm{Ma}$ ) and the beginning of the peraluminous magmatism in the Rio Doce Valley.

Tectonic models of continental collision involving significant crustal thickening (Alpine-Hymalaian type) are compatible with tectonic models proposed for the Araçuaí belt. In this sense, it is assumed in this work that the peraluminous granites from the Urucum suite were generated during late-collisional stage, similarly to what was interpreted for the $S$-type granites of the Rio de Janeiro state (Machado \& Dehler 2002).

\section{ACKNOWLEDGMENTS}

The authors (Machado R. and Nalini Jr. H.A.) thank the National Council for Scientific and Technological Development (CNPq) for the concession of productivity in research grants (processes 300423/82-9 and 303810/2010, respectively). The authors also thank the comments and suggestions of the two anonymous reviewers for improving of the manuscript.

\section{REFERENCES}

Almeida F.F.M., Hasui Y. 1984. O pré-cambriano do Brasil. São Paulo, Edgard Blücher, 378 p

Barbosa A.L.M., Sad J.H.G., Torres N., Melo M.T.V. 1964. Geologia das quadriculas Barra do Cuité e Conselheiro Pena, MG, Relatório do Arquivo Técnico do DGM, 64, DNPM, Rio de Janeiro, 285 p.

Batchelor R.A. \& Bowden P. 1985. Petrogenetic interpretation of granitoids series using multicationic parameters. Chemical Geology, 48:43-55.

Bilal E., Nalini Jr. H.A., Horn H., Correia Neves J.M., Giret A., Fuzikawa K., Fernandes M.L., Mello F.M., Moutte J. 1998. Granitóides neoproterozóicos da região do Rio Doce, Minas Gerais, Brasil. In: $40^{\circ}$ Congresso Brasileiro de Geologia, Belo Horizonte, Anais, p. 512-512.

Bilal E., Horn H., Nalini Jr. H.A., Mello F.M., Correia Neves J.M., Giret A., Moutte J., Fuzikawa K., Fernandes M.L. 2000. Neoproterozoic granitoid suites in southeastern Brazil. Revista Brasileira de Geociências, 30(1):51-54

Campos Neto M.C. \& Figueiredo M.C.H. 1995. The Rio Doce orogeny, southeastern Brazil. Journal of South American Earth Sciences, 8(2):143-162.

Chappell B.W. \& White J.R. 1974. Two contrasting granite types. Pacific Geology, 8:173-174.

Chappell B.W. \& White J.R. 1992. I- and S-type granites in the Lachlan Fold Belt. Transation of Royal Society Edinburg: Earth Sciences, 83(1-2):1-26.

Clemens J.D. \& Vielzeuf F.D. 1987. Fluids, P-T paths and the fates of anatetic melts in the Earth's crust. Earth and Planetary Sciences Letters, 86:287-306.

Correia Neves J.M., Pedrosa-Soares A.C., Marciano V.R.P.R.O. 1986. A província pegmatítica oriental do Brasil à luz dos conhecimentos atuais. Revista Brasileira de Geociências, 16(1):106-118.

Debon F. \& Le Fort P. 1983. A chemical-mineralogical classification of common plutonic rocks and associations. Transaction of the Royal Society of Edinburg: Earth Sciences, 73:135-149.

De Paolo D.J. 1981. Nd isotopes in the Colorado Front Range and crust-mantle evolution in the Proterozoic. Nature, 291:193-196.

England P.C. \& Richardson S.W. 1977. The influence of erosion upon the mineral facies of rocks from different metamorphic environments. Journal of Geological Society of London, 134:201-213.

England P.C. \& Thompson A.B. 1984. Pressure-temperaturetime paths of regional metamorphism I. Heat transfer during the evolution of regions of thickened continental crust. Journal of Petrology, 25:894-928.
Féboli J.J., Arioli E.A., Heineck C.A., Raposo F.O., Souza E.C. 1993. Estratigrafia. In: Féboli W.L. (org.) Programa Levantamentos Geológicos Básicos - Domingos Martins - Folha SF. 24-V-A-III. Brasília, DNPM-CPRM, p. 27-101.

Figueiredo M.C.H. \& Campos Neto M.C. 1993. Geochemistry of the Rio Doce magmatic arc, Southeastern Brazil. Anais da Academia Brasileira de Ciências, 65:63-81.

Fourcade S. 1981. Géochimie des granitoides. Thèse d'état, Paris VII, $212 \mathrm{p}$.

Harris T.M. \& Watson E.B. 1983. Kinectics of zircon dissolution and diffusion of zirconim in granitic melts of variable water content. Contribution Mineralogical Petrology, 84(1):66-72.

Harris N.B.W., Kelley S.E, Okay A.I. 1994 Post-collision magmatism and tectonics in northwest

Turkey. Contribution Mineralogical Petrology. 117:241-252.

Heilbron M., Valeriano C., Valladares C., Machado N. 1995. A orogênese Brasiliana no segmento central da Faixa Ribeira, Brasil. Revista Brasileira de Geociências, 25:245-266.

Heilbron M. \& Machado N. 2003. Timing of terrane accretion in the Neoproterozoic-Eopaleozoic Ribeira orogen (SE Brazil). Precambrian Research, 125:87-112.

Heilbron M., Pedrosa-Soares A.C., Campos Neto M.C., Silva L.C., Trouw R.A.J., Janasi V.A. 2004. A Provínica Mantiqueira. In: Mantesso-Neto V., Bartorelli A., Carneiro C.D.R., Brito Neves B.B. (eds.). O Desvendar de um Continente: A Moderna Geologia da América do Sul e o Legado da Obra de Fernando de Flávio Marques de Almeida, XIII, p. 203-234

Hollister L.S. 1993. The role of melt in the uplift and exhumation of orogenic belts. Chemical Geology, 108:31-48

Inger S. 1994. Magmagenesis associated with extension in orogenic belts: examples from the Himalaya and Tibet. Tectonophysics, 238:183-197.

Issa Filho A., Moura OJ.M., Fanton J.J. 1980. Reconhecimento de pegmatitos da província oriental brasileira entre Aimorés e Itambacuri, MG. In: $31^{\circ}$ Congresso Brasileiro de Geologia, Balneário de Camboriú, Santa Catarina, Anais, v. 3, 1552-1563.

Machado N., Valladares C., Heilbron M., Valeriano C. 1996. U/ $\mathrm{Pb}$ geochronology of the central Ribeira belt: implications for the evolution of brasiliano orogeny. Precambrian Research 79:347-361.

Machado R. 1997. Litogeoquímica e tectônica dos granitóides neoproterozóicos do cinturão Paraíba do Sul no Estado do Rio de Janeiro. Livre-docência Thesis, Instituto de Geociências. Universidade de São Paulo, São Paulo, 215 p. 
Machado R. \& Demange M. 1998. Caracterização geoquímica e tectônica dos granitóides pré-colisionais neoproterozóicos do Cinturão Paraíba do Sul no Estado do Rio de Janeiro. In: Conceição H. (ed.) Contribuição ao estudo dos granitos e rochas correlatas. SBG/Núcleo Bahia-Sergipe, Publicação Especial, 5:21-39.

Machado R. \& Dehler N.M. 2002. Revisão e discussão do significado tectônico dos granitóides do tipo-S no estado do Rio de Janeiro. Revista Brasileira de Geociências, 32(4):471-480.

Maniar P.D. \& Piccoli P.M. 1989. Tectonic discrimination of granitoids. Geological Society of American Bulletin, 101(5):635-643.

Martins V.T. 2000. Geologia isotópica do plutonismo Neoproterozóico da Faixa Araçuaí, região nordeste de Minas Gerais. MS Dissertation, Instituto de Geociências, Universidade de São Paulo, São Paulo, 187 p.

Martins V.T., Teixeira W., Noce C.M., Pedrosa-Soares A.C. 2004. Sr and Nd characteristics of Brasiliano/Pan-African granitoid plutons of the Araçuaí Orogen, Southeastern Brazil: tectonic implications. Gondwana Research, 7(1):75-89.

Monier G. \& Robert J.L. 1986. Muscovite solid solutions in the system K20-MgO-FeO-A1203-

SiO2-H2O: an experimental study at 2 kbar PH2O and comparison with natural Li-free white

micas. Mineralogical Magazine, 50:257-266.

Montel J. M. 1986. Experimental determination of the solubility of Ce-monazite in SiO2-Al2O3-K2O-Na2O melts at $800{ }^{\circ} \mathrm{C}, 2 \mathrm{kbar}$, under H2O-saturated conditions.

Geology, 14 (8):659-662.

Moura O.J.M., Fanton J.J., Arioli E.A. 1978a. Geologia da região de Galiléia - Mendes Pimentel, Minas Gerais. In: 30 Congresso Brasileiro de Geologia, Recife, Anais, v. 1, p. 26-37.

Moura O.J.M., Fanton J.J., Arioli E.A. 1978b. Pesquisa de pegmatitos na Serra do Urucum, Médio Rio Doce, MG. In: 30 Congresso Brasileiro de Geologia, Recife, Anais, v. 4, p. 1836-1850.

Nalini Jr. H.A. 1997. Caractérisation des suites magmatiques néoprotérozoïques de la region de Conselheiro Pena et Galiléia (Minas Gerais, Brésil). Etude géochimique et structurale des suitesGaliléia et Urucum et relations avec les pegmatites à éléments rares associées. Thèse de Doctorat, École des Mines de Saint Etienne et École des Mines de Paris, France, 237p

Nalini Jr. H.A., Bilal E., Paquette J.L., Pin C., Machado R. 2000a. Geochronologie $\mathrm{U}-\mathrm{Pb}$ et géochimie isotopique $\mathrm{Sr}-\mathrm{Nd}$ des granitoides neoproterozoiques des suites Galileia et Urucum, vallée du Rio Doce, Sud-Est du Brésil. Compte Rendu Academie Science Paris, 331:459-466.

Nalini Jr. H.A., Bilal E., Correia Neves J.M. 2000b. Syn-collisional peraluminous magmatism in the Rio Doce region: mineralogy, geochemistry and isotopic data of theUrucum suite (eastern Minas Gerais state, Brazil). Revista Brasileira de Geociências, 30(1):120-125.

Nalini Jr. H.A., Pin C., Machado R., Endo I., Bilal E. 2008. A importância da tectônica transcorrente no alojamento de granitos pré a sincolisionais na região do vale do médio Rio Doce: o exemplo das suítes graníticas Galiléia e Urucum. Revista Brasileira de Geociências, 38(4):741-752.

Noce C.M., Macambira M.J.B., Pedrosa-Soares A.C., Martins V.T.S., Ferreira D.C. 1999. Chronology of late proterozoic-cambrian granitic magmatism in the Araçuaí belts, eastern Brazil, based on dating by single zircon evaporation. In: Actas II South Americam Symposium on Isotope Geology, Córdoba, Argentina, p. 86-89.

Noce, C.M. \& Macambira, M.J.B. 2000. Chronology of late proterozoiccambrian granitic magmatism in the Araçuaí belts, eastern Brazil, based on dating by single zircon evaporation. Revista Brasileira de Geociências, 30(1):25-29.
Patiño Douce A.A.E. 1999. What do esperiments tell us about the relative contributions of crust and mantle to the origen of granitic magmas? In: Castro A., Fernández C., Vigneresse J.L. (eds.). Understanding Granites. Integrating New and Classical Technique. Geological Society, London, Special Publication, 168:55-75.

Patiño Douce A.E. \& Beard J.S. 1995. Dehydration-melting of biotite gneiss and quartz amphibolite from 3 to $15 \mathrm{kbar}$. Journal of Petrology, 36:707-738

Pearce J.A., Harris N.B.W., Tindle A.G. 1984. Trace element discrimination diagrams for the tectonic interpretation of granitic rocks, Journal of Petrology, 25(4):956-983.

Pedrosa-Soares A.C., Monteiro R.L.B.P., Correia-Neves J.M., Leonardos O. H., Fuzikawa K. 1987. Metasomatic Evolution of Granites, Northeast Minas Gerais State, Brazil. Revista Brasileira de Geociências, 17(4):512-518.

Pedrosa-Soares A.C., Vidal P., Leonardos O.H., Brito-Neves B.B. 1998. Neoproterozoic oceanic remnants in eastern Brazil: Further evidence and refutation of an exclusively ensialic evolution for the AraçuaíWest Congo Orogen. Geology, 26:519-522

Pedrosa-Soares A.C., Wiedemann C.M., Fernandes M.L.S., Faria L.F. Ferreira J.C.H. 1999. Geotectonic significance of the Neoproterozoic granitic magmatism in the Araçuaí belt, Eastern Brazil: a model and pertinent questions. Revista Brasileira de Geociências, 29:57-64.

Pedrosa-Soares A.C. \& Wiedemann-Leonardos C.M. 2000 Evolution of the Araçuaí Belt and its conection to the Ribeira Belt, eastern Brazil. In: Cordani U.G., Milani E.J., Thomaz Filho A., Campos D.A. (eds.) Tectonic Evolution of South America, Rio de Janeiro, Rio de Janeiro, p. 265-286.

Pedrosa-Soares,A.C., Noce C.M., Wiedemann C.M., Pinto C.P. 2001. The Araçuaí-West-Congo Orogen in Brazil: an overview of a confined orogen formed during Gondwanaland assembly. Precambrian Research, 110:307-323.

Pedrosa-Soares A.C., Noce C.M., Alkmin F.F., Silva L.C., Babinski M., Cordani U., Castañeda C., 2007. Orógeno Araçuaí: síntese do conhecimento 30 anos após Almeida 1977. Geonomos, 15(1):1-16

Pedrosa-Soares A.C., Alkmin F.F., Tack L., Noce C.M., Babinski M., Silva L.C., Martins Neto M. 2008. Similarities and differences between the Brazilian and African counterparts of the Neoproterozoic Araçuaí West Congo orogen. Geological Society Special Publication, v. 294, p. 153-172

Pedrosa-Soares A.C., De Campos C.P., Noce C.M., Silva L.C., Novo T., Roncato J., Medeiros S., Castañeda C., Queiroga G., Dantas E., Dussin I., Alkmin F. 2011. Late Neoproterozoic-Cambrian granitic magmatism in the Araçuaí orogeny (Brazil), the Eastern Brazilian Province and related mineral resources. Geological Society of London, Special Publication, 550:25-51

Pichavant M. 1981. An experimental study of the effect of boron on a water satured haplogranite at 1 kbar vapour pressure. Contribution Mineralogical Petrology, 76:430-439.

Siga Jr. O. 1986. A evolução geotectônica da porção nordeste de Minas Gerais, com base em interpretações geocronológicas. MS Dissertation, Instituto de Geociências, Universidade de São Paulo, São Paulo, 140 p.

Silva L.C., McNaughton N.J., Hartmann LA., Fletcher I.R. 2003. Zircon U-Pb SHRIMP dating of the Serra dos Órgãos and Rio de Janeiro gneissic granitic suites: implications for the (560 Ma) Brasiliano/Pan-African collage. Revista Brasileira de Geociências, 33(2):237-244.

Silva J.M.R., Lima M.I.C., Veronese V.F., Ribeiro Jr. R.N., Rocha R.M., Siga Jr. O. 1987. Geologia da Folha SE-24-Rio Doce. In: Projeto Radambrasil, 34. Rio de Janeiro, 544 p. 
Stevens G. \& Clemens J.D. 1993. Fluid-absent melting and the roles of fluids in the lithosphere: a slanted summary? Chemical Geology, 108:1-17.

Sylvester P.J. 1998. Post-collisional strongly peraluminous granites. Lithos 46:29-44.

Thièblemont S.R. \& Cabanis S.M. 1990. Utilisation d'um diagramme (Rb/100)-Tb-Ta pour la discriminatioon géochimique et létude pétrogénetique des roches magmatiques acides. Bulletin de la Société Géologique de France, series 8, section VI, v. 1, p. 23-35.

Thompson A.B. 1981. The pressure-temperature (P, T) plane viewed by geophisicists and petrologsts. Terra Congita 1:11-20.

Trouw R.A.J., Heilbron M., Ribeiro A., Paciullo F.V.P., Valeriano C.M., Almeida J.C.H., Tupinambá M., Andreis R. 2000. The central segment of the Ribeira Belt. In: Cordani U.G, Milani E.J., Thomaz Filho A., Campos D.A. (eds.) Tectonic Evolution of South America. 31 ${ }^{\text {st }}$ International Geological Congress, Rio de Janeiro, p. 287-310

Vidal Ph., Bernard-Griffths J., Cocherie A., Le Fort P., Peucat J.J., Sheppartds S.M.F. 1984. Geochemical investigations of the origin of the Manaslu leucogranite (Himalaya, Nepal). Physics Earth Planetary Interiors, 46:2279-2292.
Vieira V.S., Souza E.C., Raposo F.O., Silva L.C., Heineck. C.A. 1993. Geologia da Folha Baixo Guandú. In: Vieira V.S. (org.) Programa de levantamentos geológicos básicos do Brasil. Folha SE.24-Y-C-V Baixo Guandu, MG e ES. 1:100.000. DNPM/CPRM, Brasília, p. 15-134.

Vielzeuf D. \& Holloway J.R. 1988. Experimental determination of the fluid-absent melting relations in the politic system. Consequence for crustal differentiation. Contribution Mineralogical Petrology 98:257-276.

Watson E.B. 1979. Zircon saturation in felsic liquids: experimental data and applications to trace element geochemistry. Contribution Mineralogical Petrology, 70:407-419.

Watson E.B. \& Harrison T.M. 1983. Zircon saturation revisited: temperature and composition effects in a variety of crustal magma. Earth Planetary Letters, 64:295-304.

Watson E.B. \& Harrison T.M. 1984. Accessory minerals and the geochemical evolution of crustal magmatic systems: a summary and prospectus of experimental approaches. Physics of the Earth and Planetary Interiors, 35:19-30.

Wiedemann C.M. 1993. The evolution of the Early Paleozoic, Late- to PostCollisional Magmatic Arc of the Coastal Mobile Belt in the State of Espírito Santo, eastern Brazil. Anais da Academia Brasileira de Ciências, 65:163-181.

Arquivo digital disponível on-line no site wwww.sbgeo.org.br 